Howe, C., \& Rigi, J. (2009). Transnationalizing Desire: Sexualizing Culture and Commodifying Sexualities. Ethnos, 74(3), 297-306. http://doi.org/10.1080/00141840903053071

\title{
Transnationalizing Desire: Sexualizing Culture and Commodifying Sexualities
}

\author{
Cymene Howe \& Jakob Rigi \\ Rice University, USA \& Central European University, Budapest, Hungary
}

Sexuality, as a conceptual framework, has become a site for several social, moral, and political controversies, economic strategies, existential anxieties and ontological uncertainties. The transformation of sexuality, semiotically and in practice, particularly since the 1950s, reveals itself to be part of wider social and economic processes that have been variously described under the rubrics of 'globalization' (Appadurai 1996; Featherstone 1990; Hannerz 1989; Sassen 1998) and 'transnationalism' (Blanc et al. 1994; Glick Schiller et al. 1992), or the kindred categories of 'post-modernity' (Jameson 1991), 'late capitalism' (Mandel 1975) and a 'new imperialism' (Harvey 2005). In this special issue, we are interested in how sexuality as commodity and practice has come to stand for vast categories of meaning and experience in a transnational context. We explore how various forms of sexuality and desire inform national identities, the sexual policies of the state, and concepts surrounding commodifi cation and subjectivity. We understand 'transnationalizing desire' to be the locus of several overlapping political and cultural processes regarding the intimacies of sexuality: how desire and subjectivity are understood on 'local' levels, and in turn, how these categories of meaning and experience become appropriated and re-articulated in transnational exchanges. Central to the analytical frame works included here is how individuals and collectivities imagine the horizons of sexuality and desire, whether through legal interventions of sexual rights and responsibilities, interactions in the international marriage 'market,' or in modifying local hierarchies of sexual identity. Resonating in each of these discussions is a tension between 'local' practices, identities and values and those that are seen to be transnationally 'imported' varieties.

Intersecting systems of economic and cultural priorities have induced moments of global 'friction' (Tsing 2005). So too can sexuality be said to [End Page 297] produce similar sorts of 
'heat:' where the rub produces sparks and ultimately, fire. Sexuality — that putatively private and intimate terrain of the self — creates cultural heat in various forms, producing friction against reproductive imperatives, family forms, nationalism and cultural proprieties. As Jean and John Comaroff have described, it is 'interpersonal relations — above all, sexuality — [that have] come to stand metonymically, for the inchoate forces that threaten the world as we know it' (Comaroff \& Comaroff 2000:305). Sexuality, as it is deployed in sexual rights movements, as a sign of western encroachment, or as an ideal of 'modernity,' poses dilemmas for the public and private as well as what constitutes the 'local' as opposed to the 'global.' Precisely because sex, sexuality, sexual 'deviation,' and the reproductive mandates of much of nation building have often benefited from sequestering sexuality as a proximate, controllable, intimate and personal terrain, the transnational dimensions of conceiving 'desire' and sexuality allow us to envision new forms of intimacy, politics and ways of understanding sexuality. In this special issue, we discuss how sexuality challenges assumptions of the proximate and the intimate, or how the transnationalization of desire troubles the borders between the 'local' and the 'global.'

Provocative pandering, as with the global circulation of pornography, is one arena where sexuality circulates. But sexuality is also transformed through identity politics and social movements (Blackwood \& Wieringa 1999; Boellstorff 2003; Carrillo 2002; Howe n.d.; Lancaster 1992; Manalansan 2003; Parker 1999; Rofel 2007; Rubin 1984; Sinnott 2004), sex work (Brennan 2004; Chernoff 2003; Frank 2002) and claims of sexual subjectivity and the right to pleasure (Foucault 1985). Our discussions center on two mutually constituted processes, one bolstering the other: the sexualization of culture and the commodification of sexuality. The sexualization of culture, as we understand it, is the way in which the culture concept - as it is variously deployed in different national and transnational settings — has become saturated with sex and sexuality; it represents the ways in which sexuality is made to stand for many things, including accusations of western imperialism and infection, as well as notions of freedom and identity.

The increased commodification of sexuality appears in obvious ways in terms of images (advertising and pornography) and bodies (prostitution or sex work). The aesthetic and often consumption-driven arenas of fi $\mathrm{lm}$, music, literature, art, academic discourses, and popular culture illustrate much of the market 'impulse,' crafting ever-more desirable commodities. But commodification is also at work as sexual identities gain further traction, becoming sites [End Page 298] of consumption, and global dating and marriage industries continue to grow (Constable 2003). Conveying particular kinds of sexuality, through dress, performance and body language, may alternately facilitate or prohibit access to social networks and employment opportunities. The articles included in this issue thus address the sexualization of culture and the commodification of sexuality, in tandem, signaling new iterations of this 'variegated traffic' in sexuality as it appears across transnational terrains (Povinelli \& Chauncy 1999: 441) often shuttled by the traffic in images produced by global media sources, whether in the form of pornography (Williams 2004) or modesty campaigns (Mahmood 2005).

Diasporas of sexual cultures, such as lesbian and gay rights movements, transnational marriage markets, or ideals surrounding sexual freedom, are changing sexual politics within and across nation states. From a politically progressive point of view some of the changes surrounding sexuality and rights have yielded contradictory results. On the one hand, new forms of sexual liberty have emerged. Women's sexual agency has come to be more widely recognized and sexual 'minorities' have, in many places, gained recognition as subjects worthy of rights. The advent of sexual rights suggest that local practices may alternately copy or confound well- 
circulated forms of Euro-American sexual identity, citizenship and subjectivity. Shifts in how sexuality is conceived and practiced are often sites of conflict, trauma, violence and struggles waged upon symbolic and political landscapes. Moral panics that pivot upon media representations of sexuality, abortion provision, sex education, same-sex marriage, or moves to protect the sexual sanctity of the nation's women and children from 'imperial' or 'western' contaminative effects are but some of the ways that the sexualization of culture operates in fraught and politicized terms. Politically progressive movements have largely welcomed what appear to be substantive changes regarding sexuality, particularly those that advocate sexual and reproductive rights, access to sex education and medical interventions for HIV and STDs. However, socially conservative forces have resisted such changes because they allegedly destroy traditional values. Herbert Marcuse (1974), a socially radical commentator of his time, was perhaps particularly insightful on this count. He both welcomed the notion of sexual change and was, at the same time, critical of shifts taking place on the ground because they too neatly matched the horizon set by capitalist values that would lead to alienation. Like Marcuse and others, we find that sexual subjects are better understood as produced through histories of power and differentially married to changing particularities of 'desire.' [End Page 299]

The global emergence of movements based on sexual rights, including those of women and gays and lesbians, is a result of the confluence of feminism and sexual liberationist movements in the West and elsewhere. Sexuality, in these instances may serve as a semiotic site where political and citizen subjects are formed and find traction - precisely at a time when the nation state feels its grip faltering. These movements serve to radically unsettle explicitly 'territorialized' identities associated with family, community, state and nation, thereby creating new spaces to articulate the self in relation to society under the sign of sexuality. Achieving happiness and fulfilling personal desires may challenge deeply-rooted obligations to family, reproduction, heterosexual marriage, kinship, community, nation and state. Ideologies of honor and shame may be problematized, re-thought and, sometimes, re-entrenched. It comes as no surprise that the rise of religious fundamentalism and ethnic nationalism has been described as an expression of fear provoked, at least in part, by changes in the realm of sexuality (Hobsbawm 1990; B. Turner 1994, 2002). Socially conservative forces often consider women's reproductive labor as central to the reproduction of the nation. Women's bodies, and the sexualities associated with these bodies, represent honor to such communities and mandate the surveillance of sexuality and the policing of propriety in the name of family, God, culture and nation. Fundamentalist movements, particularly as they have been recently conceived by Christianity and Islam, have been perhaps the most outspoken and globally recognized forces in sexual policing. But anxieties about freedom and sexuality are not limited to priests, mullahs or their lay followers. Conservative public intellectuals such as Bell (1996), Huntington (2002), Fukuyama (1992), and Al-e-Ahmad (1982 [1963]) furnish these movements with quasi-theoretical tapestries.

Sexual politics, in the west and the rest of the world, illustrate internal divisions and shifting power relations. While hegemonic Western powers may hope to impose their particular vision on other nation states, there are strains of resistance to these processes. These include subalterns in the West who both inspire emancipatory impulses elsewhere in the world and at the same time take inspiration from outside the west in a reciprocal process. It has become somewhat de rigueur for conservative or reactionary forces to ostracize progressive movements particularly those that are believed to have an impact on sexuality in some way - by stigmatizing them as Western or 'liberal.' Nationalists, for example, often construct dichotomies 
between 'good' and 'evil' in regards to sexual politics, contrasting putative 'tradition' against 'modernity' and native-ness against the West. The 'West' may come [End Page 300] to represent Evil while autochthonous and native-culturalist values come to stand for Good. Because the family is often conceived as a major pillar of the state and nation, claims are asserted that women's bodies and sexualities ought to serve the common good of the nation and state. By nationalizing women's sexuality, sexual liberty, prostitution, interventions by U.S. and European NGOs, gender and sexual rights campaigns may be framed as weapons of the West, attacking a supposedly more pure and tradition-bound non-West. Putatively 'local' values are made to stand in stark opposition to 'global' or transnational discourses and practices, although people's quotidian experience may not reveal the fissures such claims would suggest.

Global communication technologies and the romantic and communicative strategies that characterize a burgeoning global marriage industry demonstrate the sexual sweep of transnational processes and the ways in which desire is negotiated. Jennifer Patico's article addresses the entrenched notion that marriages between American men and Russian women are simply tales of exploitation, a rote oscillation between instrumental interests and affective desire. Complicating the overly simplistic story of 'love' versus 'interest,' Patico addresses transnational marriage as an interface where complex global processes, institutional crises, and individual expectations around romance and desire meet. Russian women's relative material poverty operates in the context of a wider post-Soviet social and cultural context, where there is a perceived crisis, or moral panic, around notions of gender, family and masculinity. The relatively recent emergence of consumer culture - often tied to notions of sexuality - indexes a certain 'cultured' acumen. Patico underscores how the apparent dichotomies between the 'material' and the 'emotional' are integral to the configuration of desire in transnational processes. International marriage practices, in both the emotional and economic work that they do, suggest ways of deterritorializing marriage and the presumptions of locality and nation that are so often implicated in sexual and marital norms.

Anti-sexual rhetoric has varied across the board, as have the tropes it mobilizes. But there is a familiar call: one that advocates control of sexuality in the name of cultural authenticity, religious purity, family values, anti-imperialism and the interests of state and nation. Saida Hodžić documents the contours of these phenomena in Ghana where a Domestic Violence Bill that included the criminalization of marital rape incited debates between women's activists, NGOs and the government. She demonstrates how the government's opposition to the Bill, grounded in Ghanaian 'tradition,' was not meant to protect Ghanaian communities, but rather to fracture women's [End Page 301] political advocacy. Women's right to determine and exercise their sexuality, drawn from transnational discourses of women's rights, become framed as detrimental to the nation's right to cultural and political autonomy. The Ghanaian case resonates with similar confl icts in the Middle East, Southeast Asia (Ahmed 1992; Kandiyoti 1996) Central Asia (Nazpary 2001), and elsewhere. As transnationally circulated iterations of rights are reconfigured in Ghana, so too does the nation's history become rearticulated to emphasize tradition, with women's sexual autonomy and rights as the pivot point for these interventions. As local tradition, practices and national identity are more loudly asserted, 'imported' values of rights and sexual autonomy thus become their nemesis. Hodžić questions the nativist logic which positions Western influences as unproblematically negative.

The politics of sexuality provoke a thorny political question: on whose 'side' does one stand in the embattled arena of 'tradition' and 'progress' in the domain of sexuality and desire? The oscillation between the rights of individuals and rights held by collective entities (or 
'culture' — often claiming autochthonous and deeply historical tradition) poses several quandaries about how to adjudicate benefit and harm. Individual and collective rights have been perennial questions and the subject of much controversy in international human rights discourses, anthropological analyses and legal debates: whose human rights, the one or the multitude, has priority? Legal questions notwithstanding, the situation is further complicated as the sanctity of culture, as such, is deployed to substantiate rights claims. Contemporary anthropology, with some notable exceptions (T. Turner 1997; Turner \& Nagengast 1997; Merry 2005) has often evaded the question of rights by resorting to a truism: the discourse of rights may be productively re-appropriated, as a form of resistance, in the service of 'local cultures.' An inventory of cultures around the world would undoubtedly show that cultures everywhere have some antecedents that dovetail well with contemporary rights discourses. However, the ease with which 'cultures' are amenable to human rights should not blind us to the fact that around the world, there are surfeits of proponents of (so-called) cultural authenticity who find the discourse of 'rights' to infringe upon cultural autonomy. The historical significance of these sorts of clashes should not be underestimated. When oppositions between the West and the Other, or between sexual libertinage and cultural propriety, occur on the periphery with spokespersons wrapping their claims of authenticity in anti-imperialist rhetoric, the situation becomes yet more complex and value-loaded.

Ambiguities and contradictions arise when rights models, identity politics [End Page 302] and new sexual subjectivities intersect. Cymene Howe finds that in the case of Nicaragua, legal tropes, sexual rights activists' strategies, and forms of sexual identity are transforming the ways that Nicaraguans imagine sexuality as a category. Howe describes the case of a Nicaraguan woman, known in her small town as a cochóna ('dyke'), who was murdered by her female lover's husband. In the past, this woman's murder would have been understood as a 'crime of passion' and redemptive of masculine honor. However as human rights and identity politics operate more profoundly in the Nicaraguan milieu the murder came to be understood, and indeed adjudicated, on the basis of sexual identity. Drawing from a global repertoire of sexual rights, activists initiated a turn in Nicaraguan sexual politics where hate crimes against sexual minorities became newly imaginable. The recognition of sexual desire and identity allows the prosecution of discriminatory crimes; but these new modes of recognition also usher in something heretofore largely unimaginable: killing someone for 'being' a lesbian, or what Howe calls an 'epistemology of the hate crime.' As sexual rights become further transnationalized, the sexual subject as a legal entity offers both new horizons to establish equality for sexual 'minorities' and threatens longer standing notions of 'tradition' and moral hierarchy.

Sexuality, as it is increasingly tied to consumptive practices, may also become a site for challenging gender, kinship and status hierarchies. Sasha Newell describes in the case of Côte d'Ivoire that urban Ivoirian sexual antagonisms are mediated by a particular social and sexual economy, one that is all-consuming: 'the bluff.' Les bluffeurs are men and women who successfully enact urban savvy, deftly imitate western consumption, and mimic 'modernity' most convincingly. They are thus able to access sex, social networks and often, future economic sustenance. By performing certain nuances of western consumption — dressing up to move-up so that they may dress-up again — bluffeurs, male and female, challenge concepts of modernity and reality because the bluff itself becomes undressed: bluffeurs and their interlocutors are well aware that this is a game of disguises, if a serious one. The bluff in urban Ivoirian's lives troubles the neat distinctions between sex work and social networks, blurring the line between selling 
one's body and selling the image of the self as a sexual subject. The spectacle of the bluff reveals western consumption itself as spectacle, but one framed by the imperatives of economic, sexual and social contingencies. Between desire and economy, Newell's work suggests, there is little separation, and the bluff captures both of these transnational economies of exchange: carnal and cash-based. [End Page 303]

With increased economic globalization, the distinction between economic and emotional decision making is transformed; oftentimes these choices are seen to indicate shifts in social values surrounding sexuality. Thai women's marital preferences and sexual practices are the focus of Pilapa Esara's analysis of women living in a government-designated migrant 'slum community' in Bangkok. Many women, Esara finds, aspire to marry a foreign (faray) husband - idealized as a light-skinned, financially successful man from a western industrialized nation. Thai media sources and popular narratives equate women's sexual agency, autonomy and literal mobility - moving from rural to urban settings and potentially to foreign lands — as a threat to Thai tradition. But these women's aspirations also confront local constraints on women's upward mobility as they tap into, and embrace, globally circulated images, ideals and communications technologies in pursuit of foreign husbands. Esara argues that it is not that the 'West' influences or exercises a contaminative effect on Thai women, but rather women themselves engage their knowledge of 'the west' to affect changes in their own partnership decisions. Ultimately their decisions challenge values of gender, race, region and socioeconomic class in Thai society. Similar to the cases described by Hodžić and Patico, the women whose lives Esara documents engage a discursive context where western and material values are perceived as a threat to the moral order. However, in the Thai case, women's choices and marital strategies offer critiques of their structurally unequal position showing that they are not sycophants to western materialism, but interlocutors who negotiate desire, status and marital norms.

The transnationalization of desire and the global emergence of 'sexuality', semiotically and in practice have motivated new interrogations of national identity, ideals of propriety and cultural morality. At the same time, 'sexuality' has provided fertile political and semantic ground for rights bearing subjects and bodies invested with meaning. The (nearly) always heated debates surrounding sexuality suggest that intersecting moral, cultural, and political priorities challenge assumptions regarding the intimate. Just as other transnational processes have troubled the borders between the 'local' and the 'global,' so too do sexuality and desire illustrate the intimate ways in which people negotiate new identities, practices and opportunities. Tectonic shifts in the global political economic order appear in the most 'private' of places, demonstrating how consumption, kinship and politics become mediated through sexuality. This special issue of Ethnos aims to better understand how sexuality, commodification and cultural practices converge to produce a 'heat' that both sustains and proves incendiary to the ways we imagine desire. [End Page 304] 


\section{References}

Ahmed, Leila. 1992. Women and Gender in Islam: Historical Roots of a Modern Debate. New Haven: Yale University Press.

Al-e-Ahmad, Jalal. 1982. Plagued by the West (Gharbzadegi). Transl. Paul Sprachman. Delmor, NY: Caravan Books. First published in Iran 1963.

Appadurai, Arjun. 1996. Modernity at Large: Cultural Dimensions of Globalization. Minneapolis: University of Minnesota Press.

Bell, Daniel. 1996. The Cultural Contradictions of Capitalism. New York: HarperCollins.

Blackwood, Evelyn \& Saskia E. Wieringa (eds). 1999. Female Desires: Same Sex Relations and Transgender Practices Across Cultures. New York: Columbia University Press.

Blanc, Christina Szanton, Nina Glick Schiller, \& Linda Green Basch. 1994. Nations Unbound: Transnational Projects, Postcolonial Predicaments, and Deterritorialized Nation-States. New York: Routledge.

Boellstorff , Tom. 2003. I Knew It Was Me: Mass Media, 'Globalization,' and Lesbian and Gay Indonesians. In Mobile Cultures: New Media in Queer Asia, edited by Chris Berry, Fran Martin \& Audrey Yue, pp. 21-51. Durham: Duke University Press.

Brennan, Denise. 2004. What's Love Got to Do with It? Transnational Desires and Sex Tourism in the Dominican Republic. Durham: Duke University Press.

Carrillo, Hector. 2002. The Night Is Young: Sexuality in Mexico in the Time of AIDS. Chicago: University of Chicago Press.

Chernoff , John M. 2003. Hustling Is Not Stealing: Stories of an African Bar Girl. Chicago: University of Chicago Press.

Comaroff , J. \& J. L. Comaroff . 2000. Millennial Capitalism: First Thoughts on a Second Coming. Public Culture, 12(2) : 291-343.

Constable, Nicole. 2003. Romance on a Global Stage: Pen Pals, Virtual Ethnography, and 'Mail-order' Marriages. Berkeley: University of California Press.

Featherstone, Mike. 1990. Global Culture: Nationalism, Globalization and Modernity. London: Sage.

Foucault, Michel. 1985. The History of Sexuality: The Use of Pleasure, Vol. ii. New York: Pantheon Books.

Frank, Katherine. 2002. G-Strings and Sympathy: Strip Club Regulars and Male Desire. Durham: Duke University Press.

Fukuyama, Francis. 1992. The End of History and the Last Man. New York: Free Press.

Glick Schiller, Nina, Linda G. Basch \& Cristina Szanton Blanc. 1992. Towards a Transnational Perspective on Migration: Race, Class, Ethnicity, and Nationalism Reconsidered. New York: New York Academy of Sciences.

Hannerz, Ulf. 1989. Notes on the Global Ecumene. Public Culture, 1(2): 66 -75.

Harvey, David. 2005. The New Imperialism. Oxford: Oxford University Press.

Hobsbawm, Eric. 1990. Nation and Nationalism since 1780. Cambridge: Cambridge University Press.

Howe, Cymene. n.d. Mediating Sexuality: Activism and the Politics of Sexual Rights in Nicaragua. Durham: Duke University Press.

Huntington, Samuel P. 2002. The Clash of Civilizations and the Remaking of the World Order. New York: Free Press.

Jameson, Frederic. 1991. Postmodernism, or, The Cultural Logic of Late Capitalism. Durham: 
Duke University Press.

Kandiyoti, Deniz A. 1996. Gendering the Middle East: Emerging Perspectives. Syracuse: Syracuse University Press.

Lancaster, Roger. 1992. Life is Hard: Machismo, Danger, and the Intimacy of Power in Nicaragua. Berkeley: University of California Press.

Mahmood, Saba. 2005. Politics of Piety: The Islamic Revival and the Feminist Subject. Princeton: Princeton University Press.

Manalansan, Martin F. IV. 2003. Global Divas: Filipino Gay Men in the Diaspora. Durham: Duke University Press.

Mandel, Ernest. 1975. Late Capitalism. Atlantic Highlands, NJ: Humanities Press.

Marcuse, Herbert. 1974. Eros and Civilization. Boston, MA: Beacon Press.

Merry, Sally Engle. 2005. Human Rights and Gender Violence: Translating International Law into Local Justice. Chicago: University of Chicago Press.

Nazpary, Joma. 2001. Post Soviet Chaos: Violence and Dispossession in Kazakhstan. Ann Arbor: University of Michigan Press.

Parker, Richard. 1999. Beneath the Equator: Cultures of Desire, Male Homosexuality, and Emerging Gay Communities in Brazil. New York: Routledge.

Povinelli, Elizabeth \& George Chauncey. 1999. Thinking Sexuality Transnationally: An Introduction. GLQ, Special Issue: Thinking Sexuality Transnationally, 5(4): 439-50.

Rofel, Lisa. 2007. Desiring China: Experiments in Neoliberalism, Sexuality and Public Culture. Durham: Duke University Press.

Rubin, Gayle. 1984. Thinking Sex: Notes for a Radical Theory of the Politics of Sexuality. In Pleasure and Danger: Exploring Female Sexuality, edited by Carole S. Vance. New York: Routledge.

Sassen, Saskia. 1998. Globalization and its Discontents: Essays on the New Mobility of People and Money. New York: New Press.

Sinnott, Megan. 2004. Toms and Dees: Transgender Identity and Female Same-sex Relationships in Thailand. Honolulu: University of Hawaii Press.

Tsing, Anna. 2005. Friction: An Ethnography of Global Connection. Princeton: Princeton University Press.

Turner, Bryan S. 1994. Orientalism, Postmodernisim, and Globalism. London: Routledge.

- 2002. Cosmopolitan Virtue, Globalization and Patriotism. Theory, Culture \& Society, 19(1-2): 45-63.

Turner, Terrence. 1997. Human Rights, Human Diff erence: Anthropology's Contribution to an Emancipatory Cultural Politics. Journal of Anthropological Research, Special Issue: Universal Human Rights versus Cultural Relativity, 53(3): 273-91.

Turner, Terence \& Carole Nagengast (eds). 1997. Special Issue: Universal Human Rights versus Cultural Relativity. Journal of Anthropological Research, 53(3).

Williams, Linda. 2004. Porn Studies. Durham: Duke University Press. 